\title{
Fertilizer calcium as a factor affecting the voluntary intake, digestibility and retention time of pangola grass (Digitaria decumbens) by sheep
}

\author{
By M. C. REES and D. J. MINSON \\ Division of Tropical Agronomy, CSIRO, Cunningham Laboratory, \\ St Lucia, Queensland 4067, Australia
}

(Received I6 September I975-Accepted I7 March 1976)

\begin{abstract}
x. Pangola grass (Digitaria decumbens) grown with and without calcium fertilizer was cut at three stages of regrowth to measure voluntary intake of dry matter (DM) and digestibility of various components of the dried-grass diet by sheep kept in metabolism crates. To determine the extent of a simple Ca deficiency half the sheep on each diet were supplemented with $\mathrm{I} \cdot 4 \mathrm{~g}$ $\mathrm{Ca} / \mathrm{d}$. Retention times of the various dietary components in the reticulo-rumen were also determined.

2. Feeding a Ca supplement had no effect on voluntary intake or digestibility.

3. Ca fertilizer increased the Ca content of the grass from 2.2 to $3.8 \mathrm{~g} / \mathrm{kg} \mathrm{DM}$ and DM digestibility from 0.455 to $0.476(P<0.01)$ due to an increase in the digestibility of the hemicellulose.

4. Voluntary intake was increased from 38.8 to $43.2 \mathrm{~g} / \mathrm{kg}$ body-weight ${ }^{0.75}$ per $\mathrm{d}$ by $\mathrm{Ca}$ fertilizer due to an $18 \%$ reduction in the period of time the DM was retained in the reticulorumen.

5. Regressions relating voluntary intake to DM digestibility for the Ca-fertilized and control grass were significantly different $(P<0.01)$. When compared at the same DM digestibility the voluntary intake of the Ca-fertilized grass was $2.6 \mathrm{~g} / \mathrm{kg}$ body-weight ${ }^{0.75}$ per $\mathrm{d}$ higher than that of the control.

6. It was concluded that Ca fertilizer increased both DM digestibility and voluntary intake as a result of changes in the structural composition of the grass and not by a simple increase in the $\mathrm{Ca}$ content of the diet.
\end{abstract}

The calcium content of soils varies from 0.9 to $240 \mathrm{~g} / \mathrm{kg}$ (Millar, 1955) but may be increased by the application of calcium carbonate, hydroxide or sulphate. $\mathrm{Ca}$ is also present in many other fertilizers, including superphosphate which contains $210 \mathrm{~g} \mathrm{Ca} /$ $\mathrm{kg}$. Although $\mathrm{Ca}$ fertilizers are applied extensively to pastures, little is known about the effect of this element on the nutritive value of forages. Applying lime to Lespedeza sp. increased the growth rate of lambs given the hay, due to an increase in the protein content (Smith \& Hester, I948) but studies with lucerne (Medicago sativa L.) fed to rabbits gave conflicting results in the 2-year experimental period (Smith \& Albrecht, 1942). There appears to be no information on the effect of $\mathrm{Ca}$ fertilizers on the nutritive value of grass.

This paper describes the effect of $\mathrm{Ca}$ fertilizer applied to a $\mathrm{Ca}$-deficient soil (Andrew \& Bryan, I955) on the chemical composition, voluntary intake, digestibility and retention time of pangola grass (Digitaria decumbens) cut at three stages of regrowth. 


\section{EXPERIMENTAL}

\section{Diets}

Pangola grass was grown as a pure sward in replicated plots with $\circ$ and $760 \mathrm{~kg}$ fertilizer-Ca/ha on a recently cleared, lateritic, podzolic soil (Thomspon, 1958) at Beerwah in south-eastern Queensland $\left(27^{\circ} \mathrm{S},{ }_{5} 3^{\circ} \mathrm{E}\right.$; altitude $\left.15 \mathrm{~m}\right)$. When the sward was planted in January $\mathrm{r} 97 \mathrm{I}$, the Ca-treated plots received $220 \mathrm{~kg} \mathrm{Ca}$ as ground limestone/ha and in the following 23 months the grass was frequently harvested, removing IOI and $123 \mathrm{~kg} \mathrm{Ca} / \mathrm{ha}$ from the low- and high-Ca plots respectively in the preexperimental period. A further $540 \mathrm{~kg} \mathrm{Ca} / \mathrm{ha}$ was applied to the high-Ca plots in December 1972 to ensure maximum treatment difference in grass cut for indoor measurements of nutritive value.

At planting, all swards were fertilized with the following nutrients $(\mathrm{kg} / \mathrm{ha})$ according to the recommendations of Andrew \& Bryan (1955): elemental sulphur 53, phosphorus as diammonium phosphate 163 , potassium as potassium chloride 53 , copper carbonate 8 , zinc carbonate 8 , sodium tetraborate 4 , sodium molybdate 0.5 , nitrogen as ammonium nitrate and $\left(\mathrm{NH}_{4}\right)_{2} \mathrm{PO}_{4} \mathrm{I} 47$. In the subsequent 23-month establishment period, during which the plots were regularly harvested, the following were applied $(\mathrm{kg} / \mathrm{ha}): \mathrm{N}$ as $\mathrm{NH}_{4} \mathrm{NO}_{3}$ or $\left(\mathrm{NH}_{4}\right)_{2} \mathrm{PO}_{4} 4 \mathrm{I} 4, \mathrm{P}$ as $\left(\mathrm{NH}_{4}\right)_{2} \mathrm{PO}_{4} \mathrm{I}_{4}, \mathrm{~K}$ as $\mathrm{KCl} 60, \mathrm{~S} 45$.

In December 1972, all plots received (kg/ha): $\mathrm{N}$ as $\mathrm{NH}_{4} \mathrm{NO}_{3}$ and $\left(\mathrm{NH}_{4}\right)_{2} \mathrm{PO}_{4} 200$, $\mathrm{K}$ as $\mathrm{KCl} 42$; additional $\mathrm{N}$ ( $100 \mathrm{~kg}$ as $\mathrm{NH}_{4} \mathrm{NO}_{3}$ ) was applied after 6 weeks of regrowth.

The pangola grass was cut on I December 1972 using a reciprocating mower and the grass was removed and discarded. Regrowth from both the control and Cafertilized plots were cut after growing for 6, 10 and 15 weeks the replicates bulked together and dried in a batch drier with an inlet temperature of $100^{\circ}$. The dried grass was chopped into approximately $20-40 \mathrm{~mm}$ lengths, sampled for analysis and weighed into hessian sacks for storage. The proportion of leaf lamina was determined by hand separation of $500 \mathrm{~g}$ samples of cut grass taken before drying.

Dried samples of the six diets (control and Ca-fertilized grass each at 6 , ro and 15 weeks of regrowth) were ground and analysed for nine elements (see Table I) by emission spectroscopy (Johnson \& Simons, 1972). Food and faeces samples were analysed for total ash by heating at $500^{\circ}$ for $6 \mathrm{~h}$, and neutral-detergent solubles (NDS) and neutral-detergent fibre (NDF) by the method of Van Soest \& Wine (1967). Aciddetergent fibre (ADF) and lignin were determined by the method of Van Soest (1963). NDS, fibre (NDF, ADF) and lignin levels were corrected for contaminating ash and expressed as $\mathrm{g} / \mathrm{kg}$ dry matter (DM). The quantity of hemicellulose in the food was calculated as the difference between NDF organic matter and ADF organic matter. Cellulose level in the food was calculated as the difference between ADF organic matter and lignin (Van Soest, 1965 ). It is recognized that when estimated in this way neither the hemicellulose nor cellulose are $100 \%$ pure.

\section{Animals and housing}

Six-toothed Merino wether sheep weighing between 32 and $40 \mathrm{~kg}$ were used to measure voluntary intake and digestibility in a $17 \mathrm{~d}$ experimental period which in- 
cluded a $7 \mathrm{~d}$ preliminary period followed by a ro $\mathrm{d}$ measurement period. Each diet was offered $a d l i b$. to ten sheep which were drenched at the beginning of the trial with thiobendazole to reduce any effects of internal parasites. Half the sheep on each diet were drenched daily with $54 \mathrm{ml}$ water containing $\mathrm{I} \cdot 4 \mathrm{~g} \mathrm{Ca}$ as calcium chloride. The sheep were kept in individual metabolism pens (Minson \& Milford, 1968) and faeces collected in canvas bags attached to the animal by a harness (Weston, 1959). The sheep were weighed on a platform scale at the beginning and end of the $10 \mathrm{~d}$ measurement period. Metabolic size was calculated as the mean body-weight ${ }^{0.75}\left(\mathrm{~W}^{0.75}, \mathrm{~kg}\right)$. Blood samples were collected from the jugular vein at the end of the experimental period and plasma Ca determined by the method described by Gitelman (1967).

\section{Determination of voluntary food intake}

Ad lib. feeding was ensured by offering on the ist day of the preliminary period about $25^{\circ} \mathrm{g}$ food in excess of the expected voluntary intake and this level of excess food on offer was maintained throughout the study. Uneaten food was removed at the end of the $7 \mathrm{~d}$ preliminary period and the voluntary intake was determined during the next ro $\mathrm{d}$ with $250 \mathrm{~g}$ excess food. All intake values are expressed as $\mathrm{g} / \mathrm{kg} \mathrm{W}^{0 \cdot 75}$.

\section{Digestibility}

The faeces were collected daily during the period of so $d$ in which voluntary intake was measured, and dried overnight at $100^{\circ}$. At the end of the ro d period the total quantity of faecal DM produced was weighed and sampled for analysis.

\section{Food retention in the reticulo-rumen}

The retention time of each of the six diets in the reticulo-rumen was determined with the same two wethers using the steady-state technique previously described (Laredo \& Minson, 1975). The mixed sample of rumen contents was also used for the determination of $\mathrm{pH}$, total volatile fatty acid (VFA) concentration (Annison, I954), and molar proportions of individual VFA using gas-liquid chromatography (Stobbs \& Brett, 1972).

\section{RESULTS}

\section{Composition of diet}

Ca fertilizer increased the yield of DM from 5770 to $6970 \mathrm{~kg} / \mathrm{ha}$ per harvest and the level of $\mathrm{Ca}$ in the grass from a mean level of 2.2 to $3.8 \mathrm{~g} / \mathrm{kg} \mathrm{DM}(P<0.0 \mathrm{I})$ but had little effect on other dietary components (Table $\mathrm{I}$ ).

\section{Voluntary intake}

At all three stages of pasture regrowth, the voluntary intake of Ca-fertilized grass was higher $(P<0.05)$ than that of the control (Table 2, Fig. I); the mean increase being $11 \cdot 3 \%$ with no significant interactions between grass treatments, stages of regrowth or $\mathrm{Ca}$ supplementation $(P>0.05)$. Feeding a $\mathrm{CaCl}_{2}$ supplement had virtually no effect on the voluntary intake of either the Ca-fertilized or control grass; the mean changes were 0 and $-3.0 \%$ respectively (Table 2 ). 
Table I. Mean yield of dry matter (DM), and composition ( $\mathrm{g} / \mathrm{kg} \mathrm{DM})$ of 6-, ro- and 15-week regrowths of pangola grass (Digitaria decumbens) fertilized with 0 and $760 \mathrm{~kg}$ calcium/ha

(Mean values with their standard errors for three determinations for each regrowth period/treatment)

\begin{tabular}{|c|c|c|c|c|c|}
\hline & \multicolumn{2}{|c|}{ Control $\uparrow$} & \multicolumn{2}{|c|}{ Ca-fertilized $†$} & \multirow[b]{2}{*}{ Difference } \\
\hline & Mean & SE & Mean & SE & \\
\hline DM yield (kg/ha) & $577 \circ$ & 490 & 6970 & 880 & $1200 *$ \\
\hline Leaf lamina ( $\mathrm{g} / \mathrm{kg}$ total $\mathrm{DM}$ ) & 165 & 25 & 178 & 8 & I3 NS \\
\hline Calcium & $2 \cdot 2$ & 0.4 & $3 \cdot 8$ & 0.5 & $\mathrm{I} \cdot 6 * *$ \\
\hline Magnesium & $1 \cdot 2$ & $0 \cdot 1$ & $1 \cdot 4$ & 0.1 & $0.2 \mathrm{NS}$ \\
\hline Nitrogen & $16 \cdot 5$ & $1 \cdot 4$ & $16 \cdot 8$ & $1 \cdot 1$ & $0.3 \mathrm{NS}$ \\
\hline Sulphur & $1 \cdot 9$ & $0 \cdot 1$ & $\mathbf{I} \cdot 9$ & 0.2 & 0 \\
\hline Phosphorus & $1 \cdot 6$ & 0.1 & $1 \cdot 6$ & 0.1 & 0 \\
\hline Potassium & $6 \cdot 7$ & 0.9 & $6 \cdot 0$ & $x \cdot 5$ & $-0.7 \mathrm{NS}$ \\
\hline Sodium & $2 \cdot 4$ & $0 \cdot 3$ & $2 \cdot 5$ & 0.4 & $0.1 \mathrm{NS}$ \\
\hline Copper $(\mu \mathrm{g} / \mathrm{kg} \mathrm{DM})$ & 6 & $\mathbf{I}$ & 6 & 0.2 & 0 \\
\hline Zinc $(\mu \mathrm{g} / \mathrm{kg} \mathrm{DM})$ & 40 & 2 & 48 & 7 & 8 NS \\
\hline Total ash & $42 \cdot 5$ & $2 \cdot 3$ & 50.4 & $1 \cdot 4$ & $7^{\circ} 9^{* *}$ \\
\hline $\mathrm{NDF}$ & 695 & 4 & 673 & 8 & $-22 \mathrm{NS}$ \\
\hline $\mathrm{ADF}$ & 424 & 4 & 398 & 6 & $-26 * *$ \\
\hline NDS & 262 & 4 & 277 & 9 & I 5 NS \\
\hline Hemicellulose & 271 & 6 & 275 & 7 & 4 NS \\
\hline Cellulose & $33^{8}$ & 5 & 313 & 5 & $-25 \mathrm{NS}$ \\
\hline Lignin & 86 & 23 & 85 & 38 & - I NS \\
\hline
\end{tabular}

NDF, neutral-detergent fibre (Van Soest \& Wine, 1967); ADF, acid-detergent fibre (Van Soest, 1963); NDS, neutral-detergent solubles (Van Soest \& Wine, I967); NS, not significant $(P>0.05)$.

Difference between values was statistically significant: $* P<0.05, * * P<0.01$.

$\dagger$ For details of treatments, see p. 180 .

\section{Digestibilities}

The DM digestibility of the Ca-fertilized grass was 0.02I higher than that of the control grass (Table 2). Supplementation with $\mathrm{CaCl}_{2}$ had little effect on DM or organic matter digestibility (Table 2 ).

The digestibility of the cell contents, determined as NDS organic matter, was unaltered by the application of $\mathrm{Ca}$ fertilizer or by $\mathrm{CaCl}_{2}$ supplementation (Table 2). The digestibility of the NDS decreased from 0.572 in the 6-week regrowth to 0.522 in the I5-week regrowth $(P<0.05)$ with no change in the difference between the $\mathrm{Ca}$ fertilized grass and the control grass at the different stages of growth. There were no significant interactions between treatments $(P>0.05)$.

The digestibility of the hemicellulose was higher $(P<0.01)$ in the Ca-fertilized grass than in the control grass with a mean difference of 0.042 (Table 2). The digestibility of hemicellulose decreased from 0.592 in the 6-week regrowth to 0.472 in the 15-week regrowth $(P<0.01)$ with no change in the difference between the Cafertilized grass and the control grass at the different stages of regrowth. Feeding a $\mathrm{CaCl}_{2}$ supplement had little effect on the digestibility of hemicellulose (Table 2). There were no significant interactions between treatments $(P>0.05)$.

The mean digestibility of the cellulose was unaltered by the $\mathrm{Ca}$ fertilizer or $\mathrm{CaCl}_{2}$ supplementation (Table 2). However, for the 6-week regrowth the digestibility of the 


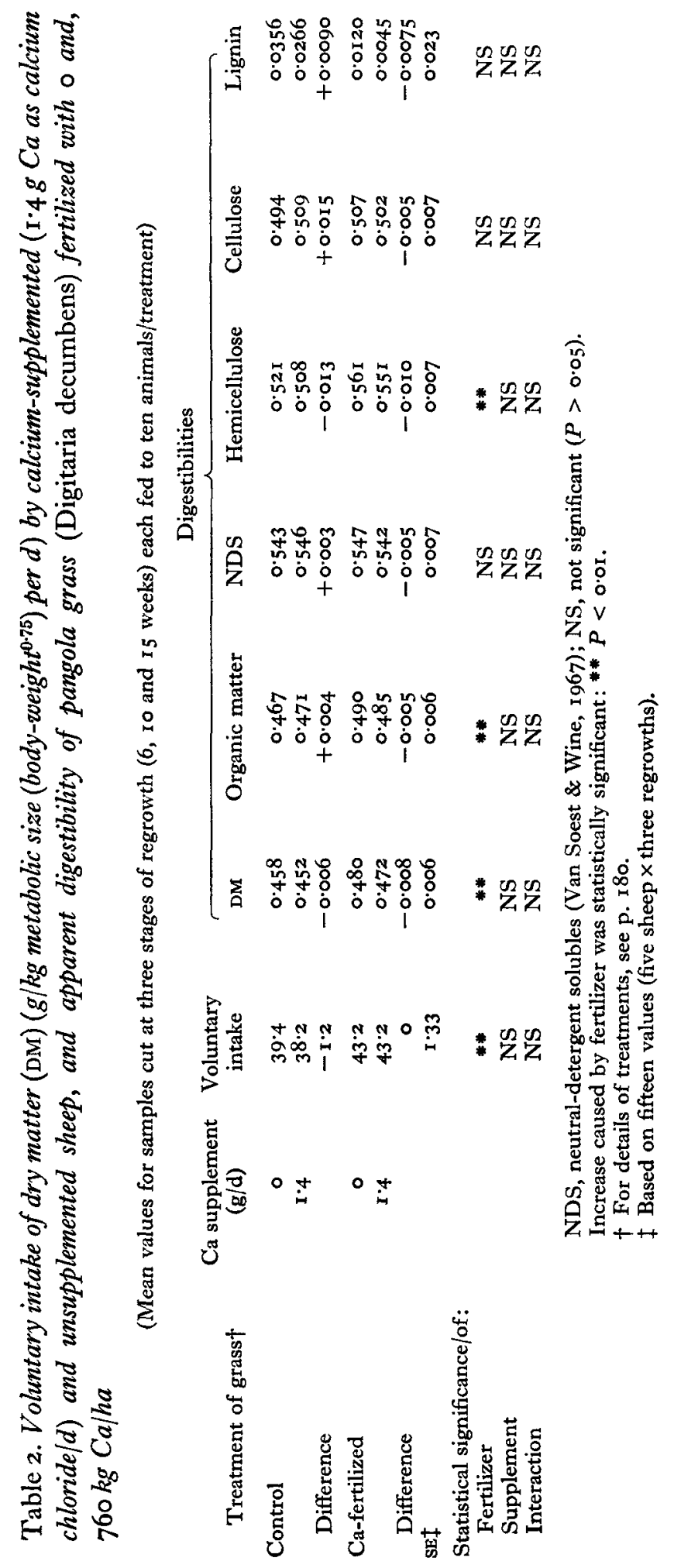




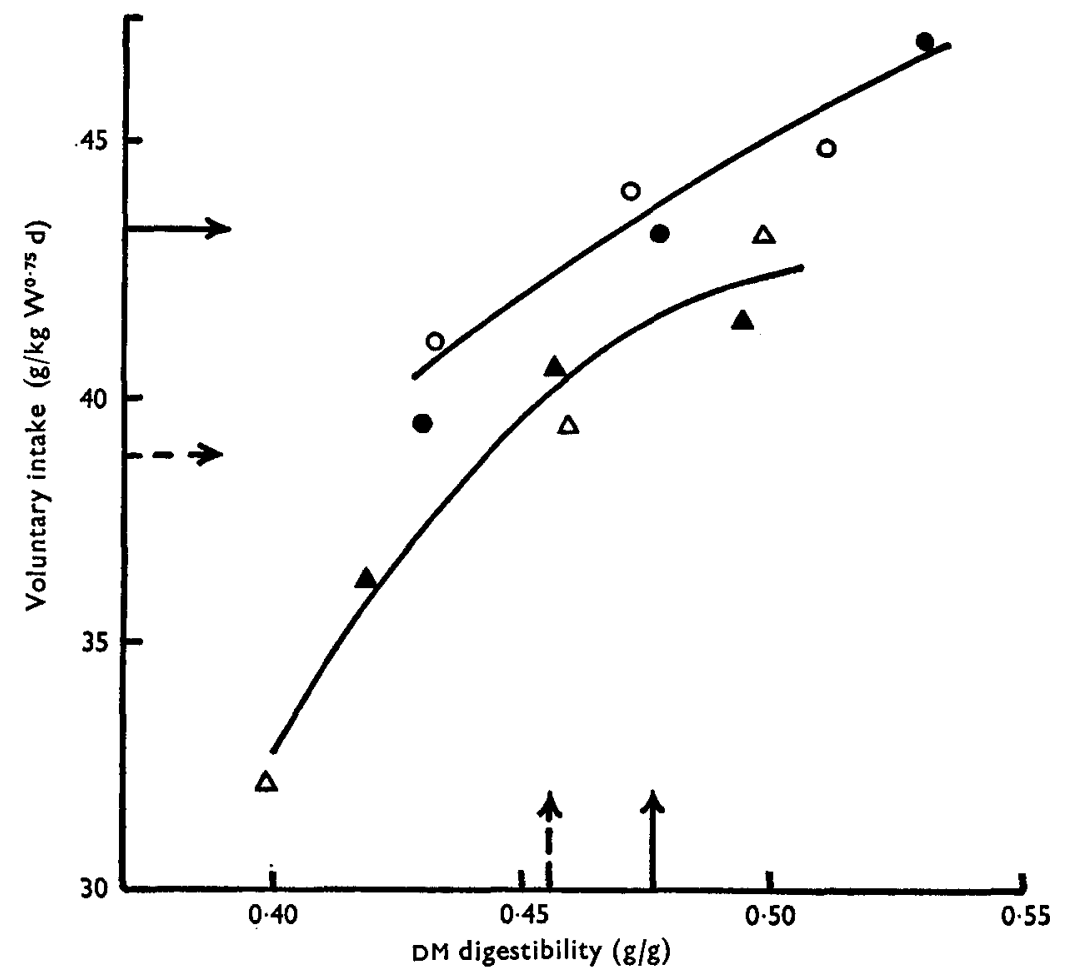

Fig. I. Effect of calcium fertilizer $(760 \mathrm{~kg} \mathrm{Ca} / \mathrm{ha})$ on the relationship between voluntary intake by Ca-supplemented ( $\mathrm{r} \cdot 4 \mathrm{~g} \mathrm{Ca}$ as calcium chloride/d) and unsupplemented sheep, and dry matter (DM) digestibility of pangola grass (Digitaria decumbens). 0 , Fertilized, no supplement;, fertilized, Ca supplement; $\triangle$, control, no supplement; $\Delta$, control, Ca supplement ; $\mathrm{W}^{0.75}$, metabolic body size (body-weight $\left.{ }^{0.75}\right) ; \rightarrow-\rightarrow$, mean value for control samples $(\Delta, \Delta)$; $\rightarrow$, mean value for fertilized samples $(\mathrm{O}, 0)$. For details of treatments see page $\mathrm{I} 80$.

cellulose in the Ca-fertilized grass was 0.05 higher than the control $(P<0.01)$ but for the ${ }_{15}$-week regrowth the cellulose digestibility was 0.024 lower in the $\mathrm{Ca}$-fertilized grass. In the 6-week regrowth the mean cellulose digestibility was $0.55^{\circ}$ compared with 0.453 in the 15 -week regrowth $(P<0.01)$. There were no significant interactions between treatments $(P>0.05)$.

The digestibility of lignin in the six diets (samples taken at three stages of regrowth for control and $\mathrm{Ca}$-fertilized grass) varied from 0.086 to -0.076 with no significant effect of either $\mathrm{Ca}$ fertilizer or $\mathrm{CaCl}_{2}$ supplementation (Table 2). There were no significant interactions between treatments $(P>0.05)$.

\section{Retention time for food in the reticulo-rumen}

Treatment with the $\mathrm{Ca}$ fertilizer reduced the mean period of time that the various components of the grass were retained in the reticulo-rumen (Table 3). NDS was retained for a shorter time than organic matter $(P<0.01)$ while hemicellulose and lignin were retained in the reticulo-rumen longer than the organic matter $(P<0.05$, Table 3). The retention time for lignin was $56 \%$ higher than that of dietary organic matter. 
Table 3. Mean retention time $(h)$ of various dietary components in the reticulo-rumen and molar proportions of individual volatile fatty acids $(V F A)(\mathrm{mmol} / \mathrm{mol})$ in the rumen of sheep given pangola grass (Digitaria decumbens) fertilized with $\circ$ and $760 \mathrm{~kg}$ calcium $/$ ha

$$
\text { (Mean values with their standard errors for 6-, 10- and i 5-week }
$$
regrowths each fed to two sheep)

\begin{tabular}{|c|c|c|c|c|c|c|c|}
\hline \multirow[b]{2}{*}{ Dietary component } & \multicolumn{2}{|c|}{ Control† } & \multicolumn{2}{|c|}{$\mathrm{Ca}$-fertilized $\uparrow$} & \multirow[b]{2}{*}{ Difference } & \multirow[b]{2}{*}{ Mean } & \multirow{2}{*}{$\begin{array}{c}\text { Relative } \\
\text { retention } \\
\text { times }\end{array}$} \\
\hline & Mean & $\mathrm{SE}$ & Mean & $\mathrm{SE}$ & & & \\
\hline Dry matter & $33^{\prime} 3$ & 0.3 & $27 \cdot 4$ & 0.9 & $5 \cdot 9^{*}$ & $30 \cdot 4^{2}$ & $\mathrm{I} \cdot 03$ \\
\hline Organic matter & $32 \cdot 3$ & 0.3 & $26 \cdot 4$ & $\mathbf{I} \cdot \mathbf{I}$ & $5 \cdot 9^{*}$ & $29 \cdot 4^{b}$ & $1 \cdot 00$ \\
\hline NDS & $2 I \cdot I$ & 0.6 & $15 \cdot 6$ & 0.6 & $5 \cdot 5 *$ & $18 \cdot 4^{\mathrm{ce}}$ & 0.62 \\
\hline Hemicellulose & $38 \cdot 4$ & $2 \cdot 0$ & $31 \cdot 9$ & $2 \cdot 0$ & $6 \cdot 5^{*}$ & $35^{\cdot} 2^{d}$ & $I \cdot 20$ \\
\hline Cellulose & $3 I \cdot 6$ & 0.1 & $29 \cdot 9$ & $4 \cdot 3$ & I.7 NS & $30 \cdot 8^{a b}$ & $1 \cdot 05$ \\
\hline Lignin & 50.3 & $I \cdot 6$ & $4 r \cdot 7$ & $4 \cdot 5$ & $8 \cdot 6^{*}$ & $46 \cdot 0$ & $1 \cdot 56$ \\
\hline NDF & $36 \cdot 7$ & 0.6 & $31 \cdot 3$ & $\mathrm{I} \cdot 7$ & $5.4^{*}$ & $34^{\circ} 0^{d}$ & $I \cdot I 6$ \\
\hline
\end{tabular}

Acetic acid

Propionic acid

Isobutyric acid

Butyric acid

Isovaleric acid

Valeric acid

Caproic acid

Total VFA $(\mathrm{mmol} / \mathrm{l})$

Rumen $\mathrm{pH}$

Molar proportions of individual VFA ( $\mathrm{mmol} / \mathrm{mol})$

a, b, c, d, Mean values with the same superscript letter were not significantly different.

NDS, neutral-detergent solubles (Van Soest \& Wine, 1967); NDF, neutral-detergent fibre (Van Soest $\&$ Wine, r 967$)$; NS, not significant $(P>0.05)$.

Difference between mean values was statistically significant: $* P<0.05$.

$\uparrow$ For details of treatments, see p. 180 .

\section{$p H$ and molar proportions of individual VFA in rumen fluid}

Fertilizing pangola grass had no consistent effect on the $\mathrm{pH}$, total concentration of VFA or on the molar proportions of individual VFA in the rumen fluid (Table 3).

\section{Blood Ca}

The mean levels of $\mathrm{Ca}$ in blood plasma of sheep were 10.1 and $10.2 \mathrm{mmol} / 1$ for control and Ca-fertilized grass respectively.

\section{DISCUSSION}

Treatment with the $\mathrm{Ca}$ fertilizer increased the voluntary intake of pangola grass by I $1 \cdot 3 \%$. Ca fertilizer also increased the $\mathrm{Ca}$ content of the grass but this was not the primary cause of the higher voluntary intake since feeding a $\mathrm{CaCl}_{2}$ supplement had no effect on voluntary intake. Thus the increased voluntary intake caused by the $\mathrm{Ca}$ fertilizer was due to some factor other than a simple mineral deficiency in the diet.

Voluntary intake of pasture is positively correlated with the digestibility of the diet (Blaxter, 1960) and in this study $\mathrm{Ca}$ fertilizer increased DM digestibility by $0.02 \mathrm{I}$ 
mainly the result of an increase in the digestibility of the hemicellulose fraction (Table 2). To determine whether this difference in digestibility was sufficient to account for the $I \mathrm{I} \cdot 3 \%$ increase in voluntary intake of the Ca-fertilized grass, separate regressions of voluntary intake $v$. DM digestibilities were calculated for the Ca-fertilized and control diets (Fig. I). These two regressions were significantly different $(P<0.01)$, and at the same DM digestibility the mean voluntary intake of the Ca-fertilized grass was $6.5 \%$ higher than that of the control grass. Thus the higher digestibility of the $\mathrm{Ca}$-fertilized grass accounted for less than half the increase in voluntary intake. This result also indicated that where voluntary intake is predicted from digestibility, using published regressions of in vivo voluntary intake $v$. digestibility, misleading estimates might be obtained where the grasses being compared are grown under different fertilizer regimens.

The voluntary intake of food is usually inversely related to the period of time the food is retained in the reticulo-rumen (Thornton $\&$ Minson, 1972) and in this study the retention time of the Ca-fertilized grass was $18 \%$ less than that of the control. This difference in retention time of food in the reticulo-rumen was sufficient to account totally for the higher voluntary intake of the $\mathrm{Ca}$-fertilized grass without the need to consider a difference in palatability. The shorter retention time of the Ca-fertilized grass was found to apply to all dietary components with the possibile exception of cellulose (Table 3 ) and may have reduced the difference in digestibility between the Ca-fertilized and control grass. If there were no change in retention time the effect of fertilizer on digestibility may have been greater since decreasing the retention time reduces digestibility. The cause of this shorter retention time of $\mathrm{Ca}$-fertilized grass in the reticulo-rumen is more difficult to explain. The only consistent difference measured between the Ca-fertilized grass and the control was the higher level of $\mathrm{Ca}$ in the food and, since feeding $\mathrm{CaCl}_{2}$ had no effect on voluntary intake, the higher intake and shorter retention time is unlikely to have been due to $\mathrm{Ca}$ per se. The slightly higher level of NDS in the Ca-fertilized grass would tend to decrease the retention time of the food since NDS had a much shorter retention time in the rumen than other dietary components, but the difference was far too small to explain the $18 \%$ shorter retention time of the Ca-fertilized grass. $\mathrm{Ca}$ is a major component of the cell wall (Russell, $195^{\circ}$; Butler \& Jones, 1973) and it is possible that the shorter retention time of the Cafertilized grass is due to structural difference in the cell wall or cross-linkages between carboxyl groups. To study this would require a different method of carbohydrate analysis than the one adopted in this work. The Van Soest system (Van Soest, I963, 1965; Van Soest \& Wine, 1967) for separating the carbohydrate fractions is widely used in routine work but has the major disadvantage of erroneously including highly digestible pectic substances in the neutral- and acid-detergent fibre fractions (Bailey \& Ulyatt, 1970). However, the level of pectic substances in pangola grass is generally $<\mathrm{I} \circ \mathrm{g} / \mathrm{kg}$ so this error would not invalidate the present results.

It was concluded that treatment with $\mathrm{Ca}$ fertilizer increased both DM digestibility and voluntary intake. The increase in voluntary intake was due to differences in the period of time food was retained in the reticulo-rumen and was not due to palatability factors. The cause of the shorter retention time of the Ca-fertilized grass is unknown 
and further work is required on factors controlling the rate of microbial breakdown of cell walls of pasture plants and the speed with which indigested particles can leave the reticulo-rumen.

The authors wish to thank Dr F. W. Smith for advice with the fertilizer rates, Messrs J. Anderson, J. Biggs, L. B. Currell and G. A. Taylor for help with the preparation and feeding of the diets, also Messrs D. J. Brett and A. Johnson for help with the chemical analyses, and Messrs M. L. Graydon, G. F. Maywald, C. Ross and P. G. Tuckett for technical assistance.

\section{REFERENCES}

Andrew, C. S. \& Bryan, W. W. (1955). Aust. F. agric. Res. 6, 265. Annison, E. F. (1954). Biochem. F. 57, 400.

Bailey, R. W. \& Ulyatt, M. J. (1970). N.Z. $\mathscr{~} l$. Agric. Res. 13, 59 r. Blaxter, K. L. (1960). Proc. 8 th int. Grassld Congr., Reading p. 479.

Butler, G. W. \& Jones, D. I. H. (1973). In Chemistry and Biochemistry of Herbage, vol, 2, p. 127 [G. W.

Butler and R. W. Bailey, editors]. London and New York: Academic Press.

Gitelman, H. J. (1967). Analyt. Biochem. 18, 521.

Johnson, A. D. \& Simons, J. G. (1972). Communs Soil Sci. Pl. Analysis 3, I. Laredo, M. A. \& Minson, D. J. (1975). Br. F. Nutr. 33, I 59.

Millar, C. E. (1955). Soil Fertility, ist ed. New York: John Wiley and Sons.

Minson, D. J. \& Milford, R. (1968). F. agric. Sci., Camb. 7r, 381.

Russell, E. J. (1950). Soil Conditions and Plant Growth, 8th ed. London: Longmans, Green \& Co.

Smith, G. E. \& Albrecht, W. A. (1942). Proc. Soil. Sci. Soc. Am. 7, 322.

Smith, G. E. \& Hester, J. B. (1948). Soil Sci. 65, 117.

Stobbs, T. H. \& Brett, D. J. (1972). Proc. Aust. Soc. Anim. Prod. 9, 297.

Thompson, C. H. (1958). Tech. Pap. Div. Soils C.S.I.R.O. Aust. no. I5/57.

Thornton, R. F. \& Minson, D. J. (1972). Aust. J. agric. Res. 23, 871.

Van Soest, P. J. (1963). F. Ass. off. agric. Chem. 46, 825.

Van Soest, P. J. (1965). F. Anim. Sci. 24, 834 .

Van Soest, P. J. \& Wine, R. H. (I967). F. Ass. off. analyt. Chem. 50, 50.

Weston, R. H. (1959). Aust. F. agric. Res. ro, 865 . 